\title{
The Determinants Stock Price Crash Risk of the Manufacturing Firms in Indonesia
}

\author{
Fidya Gumilang Arianwuri, Sutrisno T., Yeney Widya Prihatiningtias \\ Department of Accounting Faculty of Economics and Business University of Brawijaya \\ Jl. MT.Haryono No.165 Malang, 65145, Indonesia
}

\section{ABSTRACT}

Keywords:

Defender; Equity

Market Competi-

tion; Overvalued

Equities; Prospec-

tor; Stock Price

Crash Risk

JEL Cassification: G32, H54

This study aimed to examine the effect of business strategy of prospector and defender companies on stock price crash risk, test the influenced of equity market competition on stock price crash risk, and test the effect of prospector strategy on stock price crash risk through overvalued equities. The population of this study was manufacturing firms listed on the Indonesia Stock Exchange for seven years of observation. The data analysis used in this research was Path Analysis by using Multiple Linear Regression. The results of this study that the business strategy prospector positively affect the stock price crash risk, while the defender strategy was not affect the stock price crash risk. Companies that implemented business prospector strategies will be faced with higher uncertainty than defender business strategies. In addition, the prospector's business strategy can affect the stock price crash risk through overvalued equities. Companies that implemented business prospector strategies will tend to overvalued equities, which can lead to future stock price crashes. One way reduced to the stock price crash risk is in the presence of equity market competition. The equity market competition had a negative effect on the stock price crash risk, so that a high equity market competition can reduced information asymmetry and minimize the stock price crash risk.
\end{abstract}

\section{Kata kunci:}

Defender; Kompetisi

Pasar Ekuitas;

Overvalued

Equities;

Prospektor; Risiko

Crash Harga Saham

\section{ABSTRAK}

Penelitian ini bertujuan untuk menguji pengaruh strategi bisnis perusahaan prospector dan defender terhadap risiko crash harga saham, menguji pengaruh kompetisi pasar ekuitas terhadap risiko crash saham, dan menguji pengaruh strategi bisnis prospector terhadap risiko crash harga saham melalui overvalued equities. Populasi penelitian ini adalah perusahaan manufaktur yang terdaftar di Bursa Efek Indonesia selama tujuh tahun pengamatan. Analisis data yang digunakan dalam penelitian ini adalah analisis jalur dengan menggunakan regresi linier berganda. Hasil penelitian ini memberikan bukti empiris bahwa strategi bisnis prospector berpengaruh positifterhadap risiko crash harga saham, sedangkan strategi bisnis defender tidak memengaruhi risiko crash harga saham. Perusahaan yang menerapkan strategi bisnis prospector akan menghadapi ketidakpastian yang lebih tinggi daripada strategi bisnis defender. Strategi bisnis prospector dapat memengaruhi risiko crash harga saham melalui overvalued equities. Perusahaan yang menerapkan strategi bisnis prospector akan cenderung mengalami overvalued equities, yang dapat menyebabkan crash harga saham di masa depan. Salah satu cara untuk mengurangi risiko crash harga saham adalah dengan adanya kompetisi pasar ekuitas. Kompetisi pasar ekuitas berpengaruh negatif terhadap risiko crash harga saham, sehingga kompetisi pasar ekuitas yang tinggi dapat mengurangi asimetri informasi dan meminimalkan risiko crash harga saham. 


\section{Jurnal Keuangan dan Perbankan | KEUANGAN}

Vol. 21, No. 4, Oktober 2017: 575- 586

Basically, capital market investors did not observe the trend of stock price crashes, but observe stock price created in the capital market. It has weakness that stock price is not reflect the corporate performance actually. The relatively high stock prices can significantly decrease very quickly. It can be due to some management efforts in delaying informing bad news that can ultimately lead to the stock price crash risk.

Risk stock price crashes as important issue to analysis portfolio and determine price (asset pricing) (Li, Steven, \& Sue, 2016). Stock price crash risk as a condition where stock prices declined short period. Jin \& Myers (2006) argued that the crash risk is based on the concept that manager has led to hold the bad news in few times, which the bad news is not to be informed to the investor. When the bad news accumulates over the threshold, the manager will inform it to the market, which can cause increasing stock price significantly.

There are several study showed that crash risk can be happen because several factors such as, research conducted by Hutton, Marcus, \& Tehranian (2009) stated that profit management action which done by company aims to cover up the bad news to investor to certain point, therefore, can be stock price specific crash risk. Kim, Li, \& Zhang (2011a) found that tax evasion can affect the stock price crashes risk. Kim, Li, \& Zhang (2011b) showed that equity incentive between CFO and CEO can affect stock price crash risk. Based on the explanation above can be conclude that profit management, tax evasion action, equity incentive, and business strategy also as a potentially effect of stock price crash risk. For example, companies those maintain future performance expectations the investors who are too optimistic, will apply an aggressive business strategy when the company is involved in profit manipulation.

Recent research by Bentley, Omer, \& Sharp (2013) and Higgins, Omer, \& Phillips, (2015) indi- cates that business strategy which apply by company in order to keep it stable by delaying bad news to some extent. It can be conclude that company business strategy the potential to have a firstrate impact on the crash risk and lead direct economic consequences for investors. Strict business competition makes companies must have a business strategy to develop business activity. Strategy that used by company must suitable with company character and environmental conditions in order to survive in a strict business competition.

Miles et al. (1978) explain that there are 4 business strategies that may exist simultaneously, including business strategy prospector, defender, reactor, and analyzers. It is based on the difference in magnitude and changes direction in products and markets (Hambrick, 1983). Prospector typology does many changes in running the company. Defender typology runs his company with a stable without doing much change. Reactor typology is a type of company that is more pressed by the environment, because less attention to the environment changes and the competition system. Analyzer typology has a stable product market and makes changes. This is shows the prospector's competing strategy and defender is a typology of strategy that is at the opposite extreme point.

Company that implement prospector strategy has higher uncertainty outcome level, which can be asymmetry information level (Habib \& Hasan, 2017). Bentley, Newton, \& Thompson (2015) empirically, found that company manager through prospector strategy tend to delaying the bad news, because executive compensation structure (Rajagopalan, 1997), tend to tax evasion more high (Higgins, Omer, \& Philips, 2015), and litigation risk exposure. The research result explain that tend to delaying the bad news related to prospector strategy makes more susceptible to the crash risk.

The way to reduce stock price crash risk by equity market competition. How the manager hide 
the bad news consistently, probably will decline in the level of equity market competition. Investor may attempt to obtain personal information by obtaining (negative) information were not disclosed by management. However, high trade costs can reduce the incentive by reducing the present value of informed investor trading. If a higher competition level will lower the informed investors trading costs, thus increasing their willingness to get personal information and trading. This allows more information to be stored into stock prices. Therefore, if higher market competition level, the bad news possibility may lower and stock price decreasing will lower too.

Stock price crash risk also can be happen by overload equities. Conceptually the overload equities as a condition which company stock price overload fundamental value (Jensen, 2005). Besides that Jensen (2005) argue that overload equities may create agency cost which directing the manager to involved in value destruction activity. That action can be over infestation through acquisition or expansion, fraud, and manage profit (Chi \& Gupta, 2009). Overload like that, cause by much enthusiastic but unsustainable in long term. It made the company was overload.

This study as development from Habib \& Hasan (2017) and Vorst (2016). This research conducted on manufacturing company that listed to Indonesian Stock Exchange (IDX) 2010-2016. The reason to choose that as research object is manufacturing company was included in the growing industry and had great contribution on capital market development. Manufacturing companies are the industry groups whose shares are most actively traded on the Indonesia Stock Exchange, thus reflecting the overall reaction of the capital market. Manufacturing companies also have the largest number of companies in the IDX.

This study aims to analyse the effect of business prospector strategy, defender business strategy, and equity market competition to stock price crash risk and the effect business prospector strategy on stock price crash risk by overload equity.

\section{HYPOTHESES DEVELOPMENT}

\section{The Bad News Hoarding Theory}

The theory of hoarding bad news comes from the features of various strategic motivations for good and bad information in the company. Jin \& Myers (2006) found consistently evidence related to the nature of agency problems that motivated managers to control the strategy of disclosing bad news about the company to the public. Jin \& Myers (2006) found that financial motives were an important reason for managers to collect bad news within the company. Ball (2009) showed that non-financial motivation, such as maintaining the company's performance is so strong that can be the main reason for hiding negative information. Collectively, research by Jin \& Myers (2006) and Ball (2009) find that both financial and nonfinancial motives as an important role for managers enable to hold back bad news within the company.

\section{Agency Cost of Overvalued Equity}

Jensen (2005) conceptually states that overvaluation equities is a condition where the company stock price exceeds its fundamental value. Overvalued as it is often caused by excessive enthusiasm that is not sustainable in the long term (Shiller, 2000). Its makes the company more overvalued, the pressure to meet increasing the realistic revenue targets becomes greater, thus forcing manager to engage in profit manipulation to meet or beat market expectations (Jensen, 2005). Costs related to high overvalued equities, will be known by market, that company overvaluation supported by profit management and company stock price becomes degenerated or may even cause a crash (Jensen, 2005). 


\section{Jurnal Keuangan dan Perbankan | KEUANGAN}

Vol. 21, No. 4, Oktober 2017: 575- 586

\section{Stock Price Crash Risk}

Crash risk is the third moment of stock return that shows negative skewness, this is different from the previous research other steps, such as the average return (first moment), and the variant of the stock return (second moment) (Habib \& Hasan, 2017). According to Aman (2013), the stock price crashes risk is a condition when stock prices decline sharply in a relatively short time. Conceptually the risk of crashes is based on the idea that managers have a tendency to hold bad news for several time, so the bad news is not informed to investors. When the accumulation of bad news exceeds the threshold, managers will disclose the information to the market at once, which can lead to a large negative decline in stock prices (Jin \& Myers, 2006).

\section{Type of Business Strategy}

One of the determinants of corporate level in the occurrence of crash risk is caused by business strategy applied by individual companies. Each company has a different type of business strategy. Wheelen \& Hunger (2012) argue the meaning of strategy type, as follows "a strategic type is a category of firms based on a common strategic orientation of structure, culture, and processes consistent with that strategy".

Miles et al. (1978) classify appropriate typological strategies that may exist simultaneously in an industry such as, prospectors, defender, analyzer, and reactor. The prospector strategy typology focuses on product innovation, market opportunity, sales growth pursuit, and emphasizes its competition through a unique product offering (differentiation strategy). The defender strategy typology focuses on market stability and offers, and tries to protect a limited product for a narrow segment of a potential market. The analyzer typology strategy tries to take the best of both previous strategies. The reactor strategy typology a simply reacts to environmental changes and is characteristically less coherent so it cannot respond quickly to environmental changes.

\section{Equity Market Competition}

The way to reduce stock price crash risk by equity market competition. Stock prices will be more informative when high equity market competition. Higher levels of competition will lower the informed investors trading costs, thus increasing their willingness to obtain information and private trades. This allows more information to be confiscated into stock prices. Therefore, if the level of equity market competition large, the possibility of bad news can accumulate lower and the probability of a decline in stock prices is expected to be lower as well (Vorst, 2016). How the manager hide the bad news consistently, probably will decline in the level of equity market competition. Informative investor may attempt to obtain personal information by obtaining (negative) information were not disclosed by management. However, high trade costs can reduce the incentive by reducing the present value of informed investor trading.

\section{Overvalued Equities}

Jensen (2005) explains that equity overvaluation occurs when a company's stock price is higher than its underlying value. It means, companies are not able to provide the financial performance that the market needs to justify the assessment. According to Jensen \& Meckling (1976), agency costs arise when an entity, principal employs an agent. They define agency costs as the number of contracts, monitoring, and bonding costs undertaken to reduce costs due to a conflict of interest, residual cost, which occurs because it is generally impossible to synchronize the agents interests same as the principal's interests. Jensen (2005) stated that there is an expensive agency cost 


\section{The Determinants Stock Price Crash Risk of the Manufacturing Firms in Indonesia}

Fidya Gumilang Arianwuri, Sutrisno T. \& Yeney Widya Prihatiningtias

related to overvalued equities. Overvalued equities cause by much enthusiastic which unsustainable in long term.

The bad news hoarding theory explains that managers have strategic motivation to hide and accumulate bad news within the company. Habib \& Hasan (2017) argue that the stockpiling of bad news causes the stock price crash risk. Prospectors business strategy change their mix market product quickly to become innovative market leaders, while defender business strategies concentrate on a narrow and stable product base to compete on the basis of price, service or quality (Miles et al., 1978). The tendency of prospectors to withstand bad news, and subsequent higher probability of crash risk, can also be based on observations that prospectors suffer from higher levels of information asymmetry compared to defender counterparts (Kothari et al., 2009). It can be concluded that prospectors are more likely to have the future crashes risk. Based on the explanation above, this research develops the following hypotheses:

$\mathrm{H}_{1 \mathrm{a}}$ : the company prospector business strategy has effect on the stock price crash risk

$\mathrm{H}_{1 \mathrm{~b}}$ : the company defender business strategy has effect on the stock price crashes risk

If the investor is price taker, if investor trading does not affect stock prices, the market to be perfectly competitive. If the number of investors increases, the price impact of informed investor trade will decrease, thereby reducing trade costs and increasing their willingness to obtain and trade personal information. As a result, the manager's ability to accumulate bad news significantly in competitive equity markets is low, which should manifest itself in the lower probability of stock price decline. So the hypotheses of this study as follows:
$\mathrm{H}_{2}$ : equity market competition has effect on the stock price crash risk

Jensen (2005) stated that overvalued theory can be caused by a new agency cost type of overvalued equities agency costs. Overvalued can create huge welfare losses by reducing investor confidence in capital market integrity and encouraging cost-manipulation should by regulators. Excessively low equity also tends to produce inefficient results for contracts based on stock prices (Beneish \& Nichols, 2009). Habib \& Hasan (2017) argue that the prospectors' business strategy will tend to overvalued equity because there is evidence to show that investors have optimistic expectations about the prospect for stock growth (Lakonishok, Shleifer, \& Vishny, 1994; Skinner \& Sloan, 2002). Prospector business strategies are considered more overvalued, companies will have an incentive to withstand bad news to maintain the overvalued. Based on the argument above this research develops the following hypotheses:

$\mathrm{H}_{3}$ : the company prospector business strategy has effect on the stock price crash risk through overvalued equities

\section{METHODS}

This research is included in type of correlation research. This research uses independent variables in the form of business strategy that consists of company prospector business strategy and company defender business strategy, and equity market competition. Dependent variable tested is stock price crash risk, beside that there is mediation variable influence of prospector business strategy on the stock price crash risk, that is overvalued equities.

The population in this research is a manufacture company listed on the Indonesia Stock 


\section{Jurnal Keuangan dan Perbankan | KEUANGAN}

Vol. 21, No. 4, Oktober 2017: 575- 586

Exchange in 2010-2016. The selection of sampling in this research is judgment sampling. This study uses secondary data types that are quantitative in the form of annual report and stock price data in 2010-2016. Annual reports are used to obtain research variables related to stock price crashes risk, business strategy, equity market competition, and overvalued equities. Secondary data is collected from various sources from the official website of IDX, KSEEI, and Yahoo Finance.

Based on 854 observations, the company listed on manufacture sector period 2010-2016, data sample this research 224 companies.

Table 1. Research Sampling

\begin{tabular}{lr}
\hline \multicolumn{1}{c}{ Sampling Criteria } & Amount \\
\hline $\begin{array}{l}\text { Manufacture company listed on } \\
\text { Indonesian Stock Exchange 2010-2016 }\end{array}$ & 854 \\
$\begin{array}{l}\text { Number of shares with accumulated losses } \\
\text { on equity }\end{array}$ & $(210)$ \\
$\begin{array}{l}\text { The company statement with dollar } \\
\text { currency }\end{array}$ & $(189)$ \\
$\begin{array}{l}\text { Companies that do not have 26 positive } \\
\text { weekly returns }\end{array}$ & $(98)$ \\
$\begin{array}{l}\text { Unaudited financial statements } \\
\text { Research sampling number } \\
\mathrm{t}+1 \text { calculation for negative skewness }\end{array}$ & $(133)$ \\
\hline Number of final samples & 224 \\
\hline
\end{tabular}

The stock price crash risk is the significant decline risk in stock prices after prices have rise (Kim \& Zhang, 2012). This variable was measured using a model developed by Chen, Hong, \& Stein (2001) with the following formula:

$\operatorname{NCSKEW~}_{\mathrm{it}+1}=\frac{-\left(\mathrm{n}(\mathrm{n}-1)^{3 / 2} \sum \mathrm{W}_{\mathrm{it}+1}\right)^{3}}{(\mathrm{n}-1)(\mathrm{n}-2)\left(\sum \mathrm{W}_{\mathrm{it}+1^{2}}\right)^{3 / 2}}$

The company's business strategy is a strategy that companies use to adapt to a competitive environment. The business strategy measurement is based on the research of Habbe (2001) and Kallapur \& Trombley (1999). The indicator variable from the prospector company proxy and defender formulated as follows:

$\begin{array}{ll}\text { KARPEN } & =\mathrm{KAR} / \text { PENJ } \\ \text { PBV } & =\mathrm{MV} / \mathrm{BV} \\ \text { CETA } & =(\mathrm{CEt}-\text { Cet- } 1) / \mathrm{TAt}-1 \\ \text { CEMVA } & =(\text { CEt-Cet- } 1) / \mathrm{MVEt}-1\end{array}$

Research by Habbe (2001) stated that Principal Component Analysis consists of 3 values, namely four indicator variables communalities, eigen values for reduction of correlation matrix, and correlation between factors with four indicators. The value communalities summed had same value with value (factor $1+$ factor 2 ) from eigen values. Factor 1 and factor 2 are indicators of represent variables CARPEN, PBV, CEMVE, and CETA after being extracted with principal component analysis. While fac_sum is the sum variable of factor 1 and factor 2 score, which is index to classify the company prospector typologi or defender typologi. Prospector typologi or defender typologi company determine based on second index sum (factor 1 + factor 2). Index sum (fac_sum) then rated.

Equity market competition measure by number company investor by natural logaritma. This measurement based on research by Armstrong et al. (2011) and Vorst (2016). This research used 2 measurment which used for determined overvlued equities such PE (Price to Earning) and PB (Price to Book). Its based on research conducted by Habib, Gong, \& Hossain (2013). Selection of the measurement is selected because it can assist in terms of the company and the investor in detecting the company's equity condition overvalued or not.

Data analisys in this research uses Path Analisys by SPSS ver 20.0. Data analisys in this research including descriptive statistics, regresi robust test, hypotheses test, and path analisys value. 


\section{RESULTS}

\section{Prospector Typologi and Defender Typologi Company Selection}

Table 2 shows the principal component analysis results on four indicators or organizational strategy proxy. In Table 2, it can be seen that the communalities indicator value of organizational strategy. Communalities are used to determine the representational factors numberor indigenous variables that are shared with all the variables included in the analysis. The fourth value of communalities is 2.936. To achieve that value required 2 factors that have eigen values above one, that is one 1.927 and factor two 1.009. This is suitable with the rule of thumb that factor have equal eigenvalues or more than one (Habbe, 2001).

Based on factor analysis was done, obtained 96 company implement prosoector strategy, and 96 company implement defender strategy from 192 company as research samples.
The average value of stock price crashes risk by negative skewness measurement value or CRASH is -0.0005 with deviation standard is 0.25325 . Crash risk minimum value is -0.76 and maximum value is 0.98 . If the higher negative skewness value will higher tendency of the company have stock price crash risk.

Business strategy measured by factor analysis shows an average value is 0.0561 with a standard deviation is 1.510. Business strategy minimum and maximum value -1.46 and 14.04. Higher deviation standard value compared with average value indicated that higher variation between minimum and maximum value during the observation period that there is a large gap in the company business strategy variable.

Equity market competition (EMCOMP) which measure by natural logaritma, number of investor that listed on Indonesian Stock Exchange, showed average value is 2.556 with standard deviation 0.030 . Equity market competition minimum

Table 2. Principal Component Analysis Variable Indicator Strategy Organizational

A. Communality of the four indicator variables

Variable

Communalities

KARPEN

PBV

0.479

CETA

CEMVE

B. Eigenvalues for reduction of the correlation matrix

Factor 1

Eigenvalues

1.927

2
1.009

3.990

4

C. Correlation between factors with four indicators Indicator

Factor 1

KARPEN

PBV

Factor 2

$-0.021$

$-0.021$

0.689

0.729

Table 3. Statistics Descriptive

\begin{tabular}{lccccc}
\hline \multicolumn{1}{c}{ Variable } & $\mathbf{N}$ & Minimum & Maximum & Mean & Standard Deviation \\
\hline CRASH & 192 & -0.76 & 0.98 & -0.0005 & 0.25325 \\
(NCSKEW) & & & & & \\
STRATEGY & 192 & -1.46 & 14.04 & 0.0561 & 1.51038 \\
EMCOMP & 192 & 2.53 & 2.62 & 2.554 & 0.03015 \\
PB & 192 & 0.12 & 62.93 & 5.2774 & 10.1292 \\
PE & 192 & 1.73 & 113 & 19.4281 & 14.4535 \\
\hline
\end{tabular}




\section{Jurnal Keuangan dan Perbankan | KEUANGAN}

Vol. 21, No. 4, Oktober 2017: 575- 586

value is 2.53 and maximum value 2.62 . If the higher equity market competition value, will higher too investor competition in capital market.

Overvalued equity variable measure through 2 measurement PB and PE. Overvalued equity measurement through PBV showed the average 5.277 with deviation standard is 10.129 . The average value indicates that the per share price of the company has reached 5.277 equity per share. Lower PB ratio is 0.12 and higher PB is 62.92. Deviation standard $\mathrm{PBV}$ which higher than average value indicates that high variation between minimum and maximum value during observe period that there is high gap in the overvalued equity variables through $\mathrm{PB}$ measurement.

Overvalued equity variable measure through PE indicates the average is 19.428 with deviation standard is 14.453 . It indicate that company per share price has reached 19.428 of profit per share. Lower PB ratio is 1.73 and higher PB ratio is 113.00. Lower PE standard deviation value compare with average value indicate that low variation between minimum and maximum during observe period that there is no overvalued equity variable high gap with PB measurement.

\section{Robustness Standard Error Testing}

The method to overcome outlier is robust regression. Robust regression is regression method used when residual distribution upnormal or consist of outliers which influence to model. The aim to use the robust regression to get robust best model to outlier.

$\mathrm{H}_{1 \mathrm{a}}$ stated that prospector strategy had the effect on stock price crash risk. Based on the test is shown that prospector strategy variable has significancy value is $0.032(<0.05)$ with coefficient regression is 0.022 and $t$ is 2.174. So the $\mathrm{H}_{1 \mathrm{a}}$ is accepted.

$\mathrm{H}_{1 \mathrm{~b}} \quad$ stated that defender strategy had the effect on stock price crash risk. Based on the test is shown that defender strategy variable has sicnificancy value $0.604(>0.05)$ with regeression coefficient is -0.028 and $t$ is -0.520 . So the $\mathrm{H}_{1 \mathrm{~b}}$ is rejected. Its indicate that defender strategy has no effect on the stock price crash risk.

Second hypotheses stated that equity market competition had the effect on the stock price

Table 4. First Hypotheses Test

\begin{tabular}{ccccc}
\hline Unstandardized Coefficient (B) & $\mathbf{T}$ & Sig & $\mathbf{R}^{2}$ & Information \\
\hline 0.022 & 2.174 & 0.032 & 0.038 & $\mathrm{H}_{1 \mathrm{a}}$ accepted \\
-0.028 & -0.52 & 0.604 & -0.008 & $\mathrm{H}_{1 \mathrm{~b}}$ rejected \\
\hline
\end{tabular}

Table 5. Second Hypotheses Test

\begin{tabular}{ccccc}
\hline Unstandardized Coefficient (B) & $\mathbf{t}$ & Sig & $\mathbf{R}^{\mathbf{2}}$ & Information \\
\hline$-3,654$ & $-6,659$ & 0,000 & 0,185 & $\mathrm{H}_{2}$ accepted \\
\hline
\end{tabular}

Table 6. Prospector Strategy Business Testing on the Overvalued Equity

\begin{tabular}{cccc}
\hline Unstandardized Coefficient (B) & $\mathbf{t}$ & Sig & R2 \\
\hline 0.499 & 5.586 & 0.000 & 0.241 \\
\hline 0.889 & 18.831 & 0.000 & 0.788 \\
\hline
\end{tabular}


crash risk. Based on test is shown that equity market competition has sicnificant value is $0.000(<0.05)$ with regression coeffisien is -3.654 and $t$ is -6.659 . So the $\mathrm{H}_{2}$ is accepted.

Third hyposthesis testing stated that the prospector strategy effect on the stock price crash risk through overvalued equity by sicnificant $t$ and coefficient in the regerssion model or equation 3. In the regression model 3 , coefficient regression and $t$ mediation variable by PB measurement are 0.002 and 2.431 with significance $0.017(<0.05)$. That result testing show that prospector business styrategy had the effect on the stock price crash risk through $\mathrm{PB}$ as a overvalued equity mesurement. Beside that, regression coefficient and $t$ mediation variable through PE measurement are 0.001 and -3.140 with sicnificancy $0.002(<0.05)$. The testing result show that prospector business strategy had the effect on the stock price crash risk through PE as overvalued equity measurement.

\section{DISCUSSION}

First hypotheses stated that prospector strategy had the effect on stock price crash risk. The testing result show that first hypotheses accepted. This result supported the previous research by Habib \& Hasan (2017), that the prospector strategy tends to cause the stock price crash risk.

Company business strategy as a factor that cause the stock price crash risk. According to research by Miles et al. (1978) regarding company business strategy, there are 4 company business strategy. Business strategy type main focus in the research by Miles et al. (1978) is about prospector and defender business strategy. Prospector strategy as a business strategy type which more focus on the new product innovation, pursuit of market growth, and emphasizing competition through unique product offerings, so that with the company implementing the prospector business strategy is more faced with higher uncertainty risk.

First hypotheses (b) stated that defender strategy had the effect on stock price crash risk. The testing result show that first hypotheses (b) rejected. This study try to research whether defender strategy had the same effect with prospector strategy. Based on test has been done, showed that defender strategy has no sicnificant effect on the stock price crash risk. This is due to defender strategy focus on market stability and concern to long term stability which limited the product type produce by company, so the possibility stock price crash risk in this strategy is low.

Second hypotheses stated that equity market competition had the effect on the stock price crash risk. The testing result show that second hypotheses is accepted. This result supported the previous result conducted by Chen, Hong, \& Stein (2001) and Vorst (2016), that equity market competition tends to reduce the stock price crash risk.

Strong equity market competition can increase the level where personal information reflected at stock price so that decrease manager capability to hide the bad news, so there is no possibility of a decrease in the lower stock prices. According to research by Chen, Hong, \& Stein (2001), researchers found that an increase in stock sales revenue, positively predicted crash risk and negative return decline.

Table 7. Strategy Business Testing on the Stock Price Crash Risk Through Overvalued Equity

\begin{tabular}{ccccc}
\hline Unstandardized Coefficient (B) & $\mathbf{t}$ & Sig & $\mathbf{R}^{\mathbf{2}}$ & Information \\
\hline 0.264 & 2.613 & 0.010 & 0.074 & $\mathrm{H}_{3}$ accepted (PB) \\
0.719 & 3.372 & 0.001 & 0.095 & $\mathrm{H}_{3}$ accepted (PE) \\
0.218 & 2.160 & 0.033 & 0.074 & $\mathrm{H}_{3}$ accepted (PB) \\
0.563 & 2.639 & 0.010 & 0.095 & $\mathrm{H}_{3}$ accepted (PE) \\
\hline
\end{tabular}




\section{Jurnal Keuangan dan Perbankan | KEUANGAN}

Vol. 21, No. 4, Oktober 2017: 575- 586

Third hypotheses stated that the prospector strategy had effect on the stock price crash risk through overvalued equity. The testing result show that third hypotheses is accepted. This result supported the previous research by Habib \& Hasan (2017), showed that prospector business strategy had effect on the stock price crash risk through overvalued equity by $\mathrm{PB}$ and PE measurement.

The effect of overvalued equity on the stock price crash risk related to theory by Jensen (2005) stated that manager has incentive to extend missevaluation through profit manipulation. Overvalued equity increase investor expectation about company future. Overvalued equity leads to opportunistic earnings management that can destroy values and financial statements which can undermine the ability of the capital market to enter company-specific information gradually into stock prices. The prospector business strategy is more tends to overvalued equity due to investors' optimistic expectations about the prospect of stock growth that could lead to stock price crashes (Lakonishok, Shleifer, \& Vishny, 1994).

\section{CONCLUSION AND SUGGESTIONS}

\section{Conclusion}

The results of this study provide empirical evidence that the prospector business strategy is one factor that can increase stock price crash risk, while the defender strategy is not able to prove that it has the effect on the stock price crash risk. The results of this study also provide evidence that the risk of stock price crash can be minimized with the existence of equity market competition.

The result of this research is able to strengthen bad news hoarding theory about the hoarding of bad news can be minimized with the investor activity in finding information that happened so as to reduce asymmetry information between investor and company. The recent research result is to provide evidence that the prospector business strategy has an effect on the stock price crash risk through overvalued equities. The research result showed that the company that implement prospector business strategy susceptible on the stock price crash risk. This research also found that the company implement the prospector business strategy tend to overvalued equity which can cause future the stock price crash risk.

\section{Suggestions}

The researcher still encounter some limitations when doing the research. The limitation of this research is a few manufacture company that disclouse R\&D cost, so that should the selection of prospector and defender business strategy measures is based on previous research (Habib \& Hasan, 2017), in this research using the measurement of business strategy referenced in research by Habbe (2001) which used 4 indicators variable. Other limitation, still lack of reference on risk theory of stock price crash and agency cost of overvalued equity theory, so the stock price crash risk theory and agency cost of overvalued equity is still very limited. Suggestion of this research is to enlarge the research sample, for example not only to the manufacture company so that might to get business strategy indicator in the form of disclosure of R\&D cost (research \& development). Through this research is expected to be development for further research, so that can be additional reference about the stock price crash risk and agency cost of overvalued equities.

\section{REFERENCES}

Aman, H. (2013). An analysis of the impact of media coverage on stock price crashes and jumps: Evidence from Japan. Pacific-Basic Finance Journal, 24, 22-38.

Armstrong, C., Core, J. E., Taylor, D. J., \& Verrecchia, R. E. (2011). When does information asymmetry affect the cost of capital? Journal of Accounting Research, $49(1), 1-40$. 


\section{The Determinants Stock Price Crash Risk of the Manufacturing Firms in Indonesia}

Fidya Gumilang Arianwuri, Sutrisno T. \& Yeney Widya Prihatiningtias

Ball, R. (2009). The global financial crisis and the efficient market hypothesis: What have we learned? Journal of Applied Corporate Finance, 21(4), 8-16.

Beneish, M. D. \& Nichols, D. C. (2009). Identifying overvalued equity. Johnson School Research. Paper Series (09-09).

Bentley, K. A., Newton, N. J., \& Thompson, A. M. (2015). Business strategy and internal control over financial reporting. Working Paper. University of NewSouth Wales.

Bentley, K. A., Omer, T. C., \& Sharp, N. Y. (2013). Business strategy, financial reporting irregularities, and audit effort. Contemporary Accounting Research, 30(2), 780-817.

Chen, J., Hong, H., and Stein, J. C. (2001). Forecasting crashes: Trading volume, past returns, and conditional skewness in stock prices. Journal of Financial Economic, 61(3), 345-381.

Chi, J. D., \& Gupta, M. (2009). Overvaluation and earnings management. Journal of Banking $\mathcal{E}$ Finance, 33(9), 1652-1663.

Habbe, A. H. (2001). Pengaruh indikator makro ekonomi terhadap harga saham. Jurnal Mahasiswa Universitas Hasanuddin Makassar, 1-15.

Habib, A., Gong, R., \& Hossain, M. (2009). Overvalued equities and audit fees: A research note. Managerial Auditing Journal, 28(8), 755-776.

Habib, A., \& Hasan, M. M. (2017). Business strategy, overvalued equities, and stock price crash risk. Research in International Business and Finance, 39, 389-405.

Hambrick, D.C. (1983). Some tests of the effectiveness and functional attributes of Miles and Snow's strategic types. The Academy Managemrnt of Journal, 26(1), 5-26.

Higgins, D., Omer, T. C., \& Phillips, J. D. (2015). The influence of a firm's business strategy on its tax aggressiveness. Contemporary Accounting Research, 32(2), 674-702.

Hutton, A. P., Marcus, A. J., \& Tehranian, H. (2009). Opaque financial reports, R2, and crash risk. Journal of Financial Economics, 94, 67-86.

Jensen, M. C. (2005). Agency costs of overvalued equity. Financial Management, 34, 5-19.
Jensen, M. C., \& Meckling, W. H. (1976). Theory of the firm: Managerial behavior, agency costs, and ownership structure. Journal of Financial Economics, 3(4), 305-360.

Jin, L., \& Myers, S. C. (2006). R2 around the world: New theory and new tests. Journal of Financial Economics, 79, 257-292.

Kallapur, S., \& Trombley, M. A. (1999). The association between investment opportunity set proxies and relized growth. Journal of Business Finance $\mathcal{E}$ Accounting, 26(3\&4), 505-519.

Kim, J. B., \& Zhang, L. (2012). Accounting conservatism and stock price crash risk: firm-level evidence. Contemporary Accounting Research, 33(1), 412-441.

Kim, J. B., Li, Y., \& Zhang, L. (2011a). Corporate tax avoidance and stock price crash risk: Firm-level analysis. Journal of Financial Economics, 100, 639-662.

Kim, J. B., Li, Y., \& Zhang, L. (2011b). CEO versus CFO: Equity incentives and crashes. Journal of Financial Economics, 101, 713-730.

Kothari, S., Shu, S., \& Wysocki. P. (2009). Do managers withhold bad news? Journal of Accounting Research, 47, 241-276.

Lakonishok, J., Shleifer, A., \& Vishny, R. W. (1994). Contrarian investment, extrapolation, and risk. Journal of Finance, 49(5), 1541-1578.

Li, X., Steven, S. W., \& Xue, W. (2016). Trust and stock price crash risk: Evidence from China. Journal of Banking and Finance, 1-54.

Miles, R. E., Snow, C. C., Meyer, A, D., \& Coleman, H. J. (1978). Organizational Strategy, Structure, and Process. The Academy of Management Review, 3(3), 546-562.

Rajagopalan, N. (1997). Strategic orientations, incentive plan adoptions, and firm performance: Evidence from electric utility firms. Strategy Management Journal, 18(10), 761-785.

Shiller, R. J. (2000). Measuring bubble expectations and investor confidence. The Journal of Psychology and Financial Market, 1(1), 49-60.

Skinner, D., \&Sloan, R. (2002). Earnings surprises, growth expectations, and stock returns or don't let an earnings torpedo sink your portfolio. Review of Accounting Studies, 7(2-3), 289-312. 


\section{Jurnal Keuangan dan Perbankan | KEUANGAN}

Vol. 21, No. 4, Oktober 2017: 575- 586

Vorst, P. (2016). Equity market competition and stock price crash risk. SSRN. https://ssrn.com/abstract $=2661580$.
Wheelen, T. L., \& Hunger, J. D. (2012). Strategic management and business policy: Toward global sustainability. $13^{\text {th }}$ Edition. New Jersey: Pearson Education/ Prentice Hall. 